\title{
General practice fundholding: observations on prescribing patterns and costs using the defined daily dose method
}

\author{
M Maxwell, D Heaney, J G R Howie, S Noble
}

\begin{abstract}
Objective-To compare prescribing patterns between a group of fundholding practices and a group of non-fundholding practices in north east Scotland using a method which provides more accurate statements about volumes prescribed than standard NHS statistics.

Design-The pharmacy practice division of the National Health Service in Scotland provided data for selected British National Formulary sections over two years. Each prescription issued was converted using the World Health Organisation "defined daily dose" mechanism.

Setting-Six fundholding groups (nine practices) in Grampian and Tayside regions and six nonfundholding practices in Grampian.

Results-During the past two years both fundholding and control practices reduced the volume of their prescribing for the classes of drug analysed. The unit costs of drugs in some classes, however, rose substantially, contributing to higher costs per patient. The unit costs rose more in the control practices $(24 \%)$ than in the fundholding practices ( $11 \%$ in Tayside, $16 \%$ in Grampian).

Conclusion-The use of defined daily doses helped identify cost and volume trends in specific areas of prescribing in fundholding and control practices. The basis on which funds are set needs improving, and defined daily doses may prove useful for setting volume targets within drug classes for all practices, whether fundholding or not.
\end{abstract}

\section{Introduction}

Along with the more widely publicised reforms of primary and secondary care services the opportunity for general practitioners to hold a budget was given official status by the 1990 white paper Working for Patients. ${ }^{2}$ This became the basis of general practice fundholding, which started on 1 April 1991. Reports on the initial development of fundholding are now appearing, ${ }^{3-10}$ although the consequences of the subsequent expansion of the scheme have yet to be properly monitored.

The main focus of the early published work on fundholding has been the provision and purchase of secondary care services. Although accounting for some $40 \%$ of the total fund, the prescribing element has been less discussed. Some research has attempted to incorporate population factors into calculating the prescribing fund, but allocation has been largely based on historic levels (Prescribing Research Unit, University of Leeds, unpublished report, 1992). It has proved difficult to calculate an annual "uplift" to allow for inflation, varying drug prices, and the introduction of new and often expensive preparations. Prescribing analysis and cost (PACT) data in England and its Scottish equivalent, Scottish prescribing analysis (SPA), provide information at the level of cost per patient. The analyses of volumes of drug prescribed are limited by being presented either in terms of "prescribed items" with no allowance being made for the quantity of drug in each item or in listings of prescrip- tions of different quantity and strengths which cannot conveniently be aggregated. Thus although PACT/ SPA data are of some use at practice level, their value to managers and researchers is limited.

The World Health Organisation defined daily dose system allows conversion of prescribed substances into equivalent units of a standard defined volume. ${ }^{11}$ In a joint project with the Nordic Council on Medicines the WHO Centre for Drug Collaboration Statistics has agreed appropriate defined daily doses for most substances commonly used in primary care. ${ }^{12}$ Their anatomical, therapeutic, chemical (ATC) classification system is well established ${ }^{1314}$ and was originally created to facilitate international comparison of drugs covering both individual substances and combined preparations. The defined daily doses for a particular substance can be located in the Anatomical, Therapeutic, Chemical Manual. ${ }^{11}$ Recent work has shown how this type of measure can be adapted to allow comparisons of use across time for one class of drugs (antibiotics). ${ }^{15}$

In our study we used the defined daily dose system to compare trends in volume and cost between fundholding and control practices over two years.

Methods

DEFINED DAILY DOSES

The original Nordic version of the defined daily dose system was adapted for use in this study by an experienced pharmacist to reflect practice in the United Kingdom. The number of defined daily doses in a given period is calculated by multiplying the quantity of drug prescribed in the period by the strength of the preparation and dividing this by the WHO (or adapted) defined daily dose agreed to reflect "the assumed dose per day for the drug used on its main indication in adults." ${ }^{14}$ Appendix 1 shows a worked example for a group of five prescriptions for the $\mathrm{H}_{2}$-antagonists cimetidine, ranitidine, and omeprazole. This method therefore allows different formulations (tablets and mixtures for example), different strengths, and different quantities on a prescription to be aggregated and permits results to be expressed as the number of notional days of treatment given. It is also then possible to aggregate days of treatment prescribed for different drugs within a therapeutic class, or days of treatment prescribed between therapeutic classes.

\section{THE PRACTICES STUDIED}

Three practices in the Tayside region and six in the Grampian region of Scotland responded to a Scottish Office request to take part in a "shadow" fundholding evaluation project in 1990 to help launch fundholding. All proceeded to become real firstwave Scottish fundholding practices in July 1991 in Tayside and October 1991 in Grampian.

The three Tayside practices joined together to become holders of one fund (10 doctors; 19150 patients) and the six Grampian practices formed five fundholding units (43 doctors; 66150 patients). ${ }^{3} \mathrm{Six}$ geographically and demographically similar practices in Grampian which in 1991 were not considering 
becoming fundholders were approached and agreed to act as controls (40 doctors; 73600 patients). This allowed us to compare prescribing patterns of fundholders between two Scottish regions and between fundholders and non-fundholders from the same region.

\section{THE DATASET}

The pharmacy practice division of the Scottish Health Service made Scottish prescribing analysis data available for the nine fundholding practices and six control practices for 11 British National Formulary sections on a continuous basis from November 1990. The data used to prepare this report covered the two years to October 1992, and three "rolling years" were identified as follows: period 1-November 1990 to October 1991; period 2-May 1991 to April 1992; period 3-November 1991 to October 1992.

The original drugs selected for analysis were chosen to overlap with other clinical data being collected as part of a wider evaluation of fundholding and to cover the most important items prescribed in terms of both volume and cost. ${ }^{3}$ The groups chosen were: ulcer healing drugs (section $1 \cdot 3$ ), diuretics $(2 \cdot 2), \beta$ blockers $(2 \cdot 4)$, nitrates and calcium channel blockers $(2 \cdot 6)$, bronchodilators (3.1), inhaled corticosteroids (3.2), cromoglycate and related therapy (3.3), hypnoticsanxiolytics $(4 \cdot 1)$, antidepressants $(4 \cdot 3)$, antibacterial agents $(5 \cdot 1)$, and drugs used in rheumatic diseases and gout $(10 \cdot 1)$.

From May 1992 this list was extended to cover nine further sections, including antacids $(1 \cdot 1)$, antispasmodics (1.2), laxatives (1.6), antihypertensive agents $(2 \cdot 5)$, analgesics $(4 \cdot 7)$, antifungal agents $(5 \cdot 2)$, antiviral agents $(5 \cdot 3)$, drugs for treatment of diabetes $(6 \cdot 1)$, and sex hormones $(6 \cdot 4)$ (this last section includes female sex hormones, male sex hormones, and anabolic steroids but excludes contraceptives).

The list sizes and percentages of patients aged 65 or over for each practice were obtained every six months from routinely held health board information.

\section{Results}

FUND ALLOCATION AND SPENDING

Table I shows the fund allocated for the six fundholding groups for their first six months of fundholding, the percentage overspend or underspend at the end of that time, and the fund allocated for the subsequent full year of fundholding. The fund allocated for the first period varied from $£ 40$ to $£ 58$ per patient (equal to $£ 180000$ difference over a year for a group practice of 10000 patients) and the actual spend from $£ 40$ to $£ 59$ per patient (a difference of $£ 190000$ for a 10000 patient practice). Although the practice which spent the most per patient was the practice with the

TABLE I-Allocation of annualised prescribing funds per patient in two consecutive time periods in six fundholding groups ordered by percentage of patients over 65 years of age, with the actual spend in the first period

\begin{tabular}{|c|c|c|c|c|c|c|}
\hline \multirow[b]{2}{*}{$\begin{array}{l}\text { Fundholding } \\
\text { groups }\end{array}$} & \multirow{2}{*}{$\begin{array}{c}\% \text { Of } \\
\text { patients } \\
\text { aged } \\
\geqslant 65\end{array}$} & \multicolumn{3}{|c|}{$\begin{array}{l}\text { Fund allocation } \\
\text { ( } / \text { /patient/year) } \dagger\end{array}$} & \multicolumn{2}{|c|}{$\begin{array}{l}\text { Actual spend } \\
\text { period } 1\end{array}$} \\
\hline & & $\begin{array}{c}\text { Year } \\
1\end{array}$ & $\begin{array}{c}\text { Year } \\
2\end{array}$ & $\begin{array}{c}\% \\
\text { Uplift }\end{array}$ & $\underset{\text { patientt }}{\ell^{\prime}}$ & $\begin{array}{l}\% \text { Overspent } \\
\text { (underspent) }\end{array}$ \\
\hline $\begin{array}{l}\text { A } \\
\text { B }\end{array}$ & $\begin{array}{l}18 \cdot 5 \\
16 \cdot 2\end{array}$ & $\begin{array}{l}55 \\
46\end{array}$ & $\begin{array}{l}64 \\
50\end{array}$ & $\begin{array}{r}16 \\
9\end{array}$ & $\begin{array}{l}59 \\
46\end{array}$ & 7 \\
\hline $\begin{array}{l}\text { C } \\
\text { D }\end{array}$ & $\begin{array}{l}14 \cdot 4 \\
14 \cdot 3\end{array}$ & $\begin{array}{l}48 \\
58\end{array}$ & $\begin{array}{l}52 \\
59\end{array}$ & $\begin{array}{l}9 \\
2\end{array}$ & $\begin{array}{l}52 \\
54\end{array}$ & $\begin{array}{c}9 \\
(5)\end{array}$ \\
\hline $\begin{array}{l}\mathrm{E} \\
\mathrm{F}\end{array}$ & $\begin{array}{l}12 \cdot 5 \\
11 \cdot 8\end{array}$ & $\begin{array}{l}40 \\
44\end{array}$ & $\begin{array}{l}42 \\
46\end{array}$ & $\begin{array}{l}6 \\
2\end{array}$ & $\begin{array}{l}40 \\
42\end{array}$ & $\begin{array}{c}1 \\
(5)\end{array}$ \\
\hline
\end{tabular}

*Year 1 figures were the six month funds for October 1991-April 1992; these were doubled to produce an annual figure. Year 2 figures were the funds for the year April 1992-March 1993.

tRounded to nearest $£$; percentages based on the exact figures. highest proportion of elderly patients, there was no correlation between age and estimated or actual spend in the other five groups. The uplift in fund negotiated for the second year of fundholding ranged from $2 \%$ to $16 \%$ and did not appear to be related to actual spend or percentage saved or overspent in the previous period.

TRENDS IN PRESCRIBING COST AND VOLUME

Table II compares trends between the Tayside fundholding group, the five Grampian fundholding groups aggregated as one, and the group of six control practices. The cost per patient per year fell by $2.9 \%$ between period 1 and period 3 in Tayside while rising by $9.8 \%$ and $12.6 \%$ in the Grampian fundholding and control practices respectively. However, Tayside fundholders spent $£ 8.30$ per patient (34\%) more than Grampian fundholders in period 1. By period 3 this differential had been reduced to $£ 5(19 \%)$. The Grampian fundholders spent $£ 1.75(8 \%)$ more than the control group in period 1 ; by period 3 this differential had also reduced to $£ 1.30(5 \%)$.

TABLE II-Prescribing trends in Tayside fundholders, Grampian fundholders, and controls November 1990 to October 1992

\begin{tabular}{|c|c|c|c|c|}
\hline & $\begin{array}{c}\text { Period } \\
1\end{array}$ & $\begin{array}{l}\text { Period } \\
2\end{array}$ & $\begin{array}{c}\text { Period } \\
3\end{array}$ & $\begin{array}{l}\% \text { Change } \\
\text { from } 1 \text { to } 3\end{array}$ \\
\hline \multicolumn{5}{|c|}{ Cost per patient per year $(\emptyset)$} \\
\hline $\begin{array}{l}\text { Tayside } \\
\text { Grampian } \\
\text { Controls }\end{array}$ & $\begin{array}{l}32 \cdot 35 \\
24 \cdot 06 \\
22 \cdot 31\end{array}$ & $\begin{array}{l}32 \cdot 59 \\
25 \cdot 84 \\
24 \cdot 30\end{array}$ & $\begin{array}{l}31 \cdot 41 \\
26 \cdot 42 \\
25 \cdot 11\end{array}$ & $\begin{array}{r}-2 \cdot 9 \\
9 \cdot 8 \\
12 \cdot 6\end{array}$ \\
\hline Total & 23.97 & $25 \cdot 62$ & 26.06 & $8 \cdot 7$ \\
\hline $\begin{array}{l}\text { \% Difference between: } \\
\text { Tayside and Grampian } \\
\text { Grampian and controls }\end{array}$ & $\begin{array}{r}34 \cdot 5 \\
7 \cdot 8\end{array}$ & $\begin{array}{r}26 \cdot 1 \\
6 \cdot 3\end{array}$ & $\begin{array}{r}18 \cdot 9 \\
5 \cdot 2\end{array}$ & \\
\hline \multicolumn{5}{|c|}{ No of defined daily doses per patient per year } \\
\hline $\begin{array}{l}\text { Tayside } \\
\text { Grampian } \\
\text { Controls } \\
\end{array}$ & $\begin{array}{r}110 \cdot 9 \\
105 \cdot 6 \\
88 \cdot 2 \\
\end{array}$ & $\begin{array}{r}104 \cdot 4 \\
103 \cdot 3 \\
82 \cdot 7 \\
\end{array}$ & $\begin{array}{l}97 \cdot 3 \\
99 \cdot 9 \\
80 \cdot 0 \\
\end{array}$ & $\begin{array}{r}-12 \cdot 3 \\
-5 \cdot 3 \\
-9 \cdot 3 \\
\end{array}$ \\
\hline Total & $98 \cdot 18$ & $93 \cdot 33$ & 89.69 & $-8 \cdot 6$ \\
\hline $\begin{array}{l}\text { \% Difference between: } \\
\text { Tayside and Grampian } \\
\text { Grampian and controls }\end{array}$ & $\begin{array}{r}5 \cdot 1 \\
19 \cdot 6\end{array}$ & $\begin{array}{r}1 \cdot 1 \\
25 \cdot 0\end{array}$ & $\begin{array}{r}-2 \cdot 6 \\
25 \cdot 0\end{array}$ & \\
\hline \multicolumn{5}{|c|}{ Cost per defined daily dose $\left(\AA^{*}\right.$} \\
\hline $\begin{array}{l}\text { Tayside } \\
\text { Grampian } \\
\text { Controls } \\
\end{array}$ & $\begin{array}{l}0.29 \\
0 \cdot 23 \\
0 \cdot 25 \\
\end{array}$ & $\begin{array}{l}0 \cdot 31 \\
0 \cdot 25 \\
0 \cdot 29 \\
\end{array}$ & $\begin{array}{l}0.32 \\
0.26 \\
0.31 \\
\end{array}$ & $\begin{array}{l}10 \cdot 7 \\
16 \cdot 0 \\
24 \cdot 2 \\
\end{array}$ \\
\hline Total & $0 \cdot 24$ & $0 \cdot 27$ & $0 \cdot 29$ & $19 \cdot 0$ \\
\hline $\begin{array}{l}\text { \% Difference between: } \\
\text { Tayside and Grampian } \\
\text { Grampian and controls }\end{array}$ & $\begin{array}{l}28 \cdot 0 \\
-9 \cdot 8\end{array}$ & $\begin{array}{r}24 \cdot 8 \\
-14 \cdot 9\end{array}$ & $\begin{array}{r}22.1 \\
-15.8\end{array}$ & \\
\hline
\end{tabular}

^Rounded to the nearest pence.

When these data were converted to defined daily doses per patient there was a progressive fall in volume in all three practice groupings across the three time periods.

In particular the control practices showed an overall fall of $9 \%$ despite starting from a lower initial level. From this more precise volume statement we then calculated meaningful cost per volume figures. Table II also shows the cost per defined daily dose. This increased by $11 \%$ for Tayside fundholders, by $16 \%$ for Grampian fundholders, but by $24 \%$ for the control practices. Between period 1 and period 3 the overall cost per patient for the selected basket of drugs rose $8.7 \%$, the total volume of drug prescribed per patient fell by $8.6 \%$, and the cost per volume rose by $19 \%$.

INFLUENCE OF AGE MIX

The percentage of patients aged over 65 was $18 \%$ in Tayside, $13 \%$ for the Grampian fundholders, and $11 \%$ for the controls. The findings in table II were reexamined after converting the denominator from 
TABLE III-Prescribing trends in Tayside fundholders, Grampian fundholders, and controls November 1990 to October 1992 in terms of prescribing units

\begin{tabular}{|c|c|c|c|}
\hline & $\begin{array}{c}\text { Period } 1 \\
\% \text { Of patients over } 65\end{array}$ & Period 2 & Period 3 \\
\hline Tayside & $17 \cdot 8$ & $17 \cdot 8$ & $17 \cdot 8$ \\
\hline Grampian & $13 \cdot 4$ & $13 \cdot 4$ & $13 \cdot 4$ \\
\hline Controls & $11 \cdot 3$ & $11 \cdot 3$ & $11 \cdot 4$ \\
\hline \multicolumn{4}{|c|}{ Cost per prescribing unit $(£)$} \\
\hline Tayside & 23.86 & $24 \cdot 03$ & $23 \cdot 17$ \\
\hline Grampian & 18.97 & $20 \cdot 38$ & 20.84 \\
\hline Controls & $18 \cdot 19$ & $19 \cdot 82$ & $20 \cdot 45$ \\
\hline \multicolumn{4}{|l|}{ \% Difference between: } \\
\hline Tayside and Grampian & $25 \cdot 8$ & 17.9 & $11 \cdot 2$ \\
\hline Grampian and controls & $4 \cdot 3$ & $2 \cdot 8$ & 1.9 \\
\hline \multicolumn{4}{|c|}{ No of defined daily doses per prescribing unit } \\
\hline Tayside & $81 \cdot 79$ & $77 \cdot 00$ & $71 \cdot 77$ \\
\hline Grampian & $83 \cdot 25$ & $81 \cdot 49$ & $78 \cdot 81$ \\
\hline Controls & 71.97 & $67 \cdot 42$ & $65 \cdot 13$ \\
\hline \multicolumn{4}{|l|}{$\%$ Difference between: } \\
\hline Tayside and Grampian & $-1 \cdot 8$ & $-5 \cdot 8$ & -8.9 \\
\hline Grampian and controls & $15 \cdot 7$ & $20 \cdot 9$ & $21 \cdot 0$ \\
\hline
\end{tabular}

patients to prescribing units using the PACT procedure of regarding each patient over 65 as equivalent to 3 prescribing units, and all patients under 65 as equivalent to 1 prescribing unit. Table III shows that this change in denominator reduced the cost differential between Tayside and Grampian fundholders by about a quarter. When assessed by volume per patient (table II) the Tayside fundholders started 5\% above Grampian fundholders but ended $2.6 \%$ below by period 3. When assessed by volume per prescribing unit they were below Grampian fundholders from period 1 onwards. The cost differential between Grampian fundholders and the control practices reduced by about half when patients were converted to prescribing units, and the volume differential decreased by about a fifth. Thus age does explain some of the variance in prescribing patterns, although leaving a large proportion unexplained..$^{16}$

\section{INITIAL ANALYSIS OF TRENDS BY DRUG GROUPS}

Table IV presents similar analyses to those in tables II and III for each of the 11 British National Formulary sections-and is equally revealing. The $2 \cdot 2 \%$ drop over time in cost per patient for drugs for rheumatic diseases, for example, disguised a $22 \%$ drop in volume, coinciding with a $26 \%$ increase in cost per volume. Volume generally decreased over the three periods except for ulcer healing drugs, inhaled corticosteroids, and antidepressants. The largest decreases in volume were for cromoglycate (although the initial volume was low), hypnotics-anxiolytics, and drugs for rheumatic diseases. Cost per volume increased for all classes of drug except $\beta$ blockers, with the largest increases in cost per defined daily dose occurring for calcium channel blockers, antidepressants, and drugs for rheumatic diseases.

\section{EXTENDED ANALYSIS OF DRUG GROUPS}

The 11 British National Formulary sections used to construct table IV accounted for half the drug costs for the 15 practices studied. In May 1992 we increased the range of drugs studied by including nine further sections. Table $\mathrm{V}$ is based on the analyses of the extended list of 20 sections, which accounted for $65 \%$ of all costs (practice range 58-72\%). Six sections accounted for less than 1 defined daily dose per patient for the six months May 1992-October 1992 and these were grouped together as "others."

The information in table $\mathrm{V}$ is presented in terms of numbers of defined daily doses per patient for the 15 practices ranked in order of the proportion of their patients aged over 65 . The third of practices with the most elderly patients prescribed a significantly more defined daily doses than the third with the least $(69 \cdot 0$ for six months $v$ 52.0). The practices ranged from 44 defined daily doses per patient to 78 defined daily doses per patient; the practice with the lowest proportion of elderly patients had the lowest level of defined daily doses, but the practice with the highest level of defined daily doses ranked only 10th out of 15 in terms of proportion of elderly patients. Prescriptions of some classes of drugs seemed to correlate with age either positively (ulcer healing drugs, diuretics, and calcium channel blockers) or negatively (sex hormones). But for various classes of drugs individual practice figures showed large variations independent of age structure. For example bronchodilators showed volumes ranging from 4.3 defined daily doses (for the practice ranked 13th) to 12.6 defined daily doses (for the practice ranked 10th).

\section{Discussion}

This paper is one of a series reporting an evaluation of the first general practice fundholding project in the Grampian and Tayside areas of Scotland. It is based on a study of a geographically distinct cohort of 53 fundholding and 40 control doctors. The difficulty of defining a good control group for fundholding research is shown by the fact that during the course of this study all the control practices decided to apply to become, and have now become, fundholders. Comparisons between test and control groups must therefore be interpreted with caution. Given the analytical limitations of PACT/SPA data we have developed the WHO defined daily dose method of examining prescribing information, and a byproduct of this study has been the demonstration that future thinking about measuring

TABLE IV-Analysis of prescribing patterns by British National Formulary group for Tayside fundholders, Grampian fundholders, and controls

\begin{tabular}{|c|c|c|c|c|}
\hline & $\begin{array}{c}\text { Period } \\
1\end{array}$ & $\begin{array}{l}\text { Period } \\
2\end{array}$ & $\begin{array}{c}\text { Period } \\
3\end{array}$ & $\begin{array}{l}\% \text { Change } \\
\text { from } 1 \text { to } 3\end{array}$ \\
\hline \multicolumn{5}{|c|}{ Cost per patient $(£)$} \\
\hline Ulcer healing drugs & 4.96 & $5 \cdot 40$ & $5 \cdot 67$ & $14 \cdot 3$ \\
\hline Diuretics & 1.26 & 1.27 & 1.23 & $-2 \cdot 4$ \\
\hline$\beta$ blockers & 1.58 & 1.54 & 1.43 & $-9 \cdot 5$ \\
\hline Nitrates, calcium channel blockers & 3.05 & $3 \cdot 24$ & $3 \cdot 38$ & $10 \cdot 8$ \\
\hline Bronchodilators & 2.52 & 2.77 & $2 \cdot 86$ & 13.5 \\
\hline Corticosteroids & 1.93 & $2 \cdot 13$ & $2 \cdot 24$ & $16 \cdot 1$ \\
\hline Cromoglycate and related drugs & 0.32 & 0.33 & 0.31 & $-3 \cdot 1$ \\
\hline Hypnotics-anxiolytics & 0.40 & 0.38 & $0 \cdot 38$ & $-5 \cdot 0$ \\
\hline Antidepressants & 1.03 & 1.33 & 1.65 & $60 \cdot 2$ \\
\hline Antibacterial drugs & $3 \cdot 21$ & $3 \cdot 45$ & $3 \cdot 28$ & $2 \cdot 2$ \\
\hline Drugs for rheumatic diseases, gout & $3 \cdot 71$ & $3 \cdot 78$ & 3.63 & $-2 \cdot 2$ \\
\hline Total & 23.97 & $25 \cdot 62$ & 26.06 & $8 \cdot 7$ \\
\hline
\end{tabular}

\begin{tabular}{|c|c|c|c|c|}
\hline \multicolumn{5}{|c|}{ No of defined daily doses per patient } \\
\hline Ulcer healing drugs & 5.53 & $5 \cdot 95$ & $6 \cdot 21$ & $12 \cdot 3$ \\
\hline Diuretics & 23.92 & $23 \cdot 47$ & $22 \cdot 53$ & $-5 \cdot 8$ \\
\hline$\beta$ blockers & $6 \cdot 20$ & $6 \cdot 10$ & $5 \cdot 76$ & $-7 \cdot 1$ \\
\hline Nitrates, calcium channel blockers & $9 \cdot 76$ & 9.04 & 8.39 & $-14 \cdot 0$ \\
\hline Bronchodilators & $14 \cdot 64$ & 13.96 & 13.69 & $-6 \cdot 5$ \\
\hline Corticosteroids & 4.49 & 4.59 & 4.79 & $6 \cdot 7$ \\
\hline Cromoglycate and related drugs & 0.39 & 0.24 & $0 \cdot 31$ & $-20 \cdot 5$ \\
\hline Hypnotics-anxiolytics & $9 \cdot 26$ & $8 \cdot 64$ & $7 \cdot 93$ & $-14 \cdot 4$ \\
\hline Antidepressants & $3 \cdot 25$ & $3 \cdot 38$ & $3 \cdot 44$ & $5 \cdot 8$ \\
\hline Antibacterial drugs & $4 \cdot 31$ & $4 \cdot 31$ & $3 \cdot 85$ & $-10 \cdot 7$ \\
\hline Drugs for rheumatic diseases, gout & $16 \cdot 43$ & 13.65 & $12 \cdot 79$ & $-22 \cdot 2$ \\
\hline Total & $98 \cdot 18$ & 93.33 & 89.69 & $-8 \cdot 6$ \\
\hline
\end{tabular}

\begin{tabular}{lcccr}
\hline \multicolumn{5}{c}{ Cost per defined daily dose $(£)$} \\
Ulcer healing drugs & 0.90 & 0.91 & 0.91 & 1.8 \\
Diuretics & 0.05 & 0.05 & 0.05 & 3.6 \\
$\beta$ blockers & 0.25 & 0.25 & 0.25 & -2.6 \\
Nitrates, calcium channel blockers & 0.31 & 0.36 & 0.40 & 28.9 \\
Bronchodilators & 0.17 & 0.20 & 0.21 & 21.4 \\
Corticosteroids & 0.43 & 0.46 & 0.47 & 8.8 \\
Cromoglycate and related drugs & 0.82 & 1.38 & 1.00 & 21.9 \\
Hypnotics-anxiolytics & 0.04 & 0.04 & 0.05 & 10.9 \\
Antidepressants & 0.32 & 0.39 & 0.48 & 51.3 \\
Antibacterial drugs & 0.74 & 0.80 & 0.85 & 14.4 \\
Drugs for rheumatic diseases, gout & 0.23 & 0.28 & 0.28 & 25.7 \\
\hline \multicolumn{1}{c}{ Total } & 0.24 & 0.27 & 0.29 & 19.0 \\
\hline
\end{tabular}

^Rounded to nearest pence. 


\begin{tabular}{|c|c|c|c|c|c|c|c|c|c|c|c|c|c|c|c|c|c|c|}
\hline Practice & $\begin{array}{c}\begin{array}{c}\% \text { Of } \\
\text { patients } \\
\text { aged } \\
\geqslant 65 \\
>65\end{array} \\
\end{array}$ & $\begin{array}{c}\text { Ulcer } \\
\text { healing } \\
\text { drugs } \\
\end{array}$ & Laxatives & Diuretics & $\beta$ blockers & $\begin{array}{l}\text { Nitrates, } \\
\text { calcium } \\
\text { channel } \\
\text { blockers } \\
\end{array}$ & Bronchodilators & Corticosteroids & $\begin{array}{l}\text { Hypnotics- } \\
\text { anxiolytics }\end{array}$ & Antidepressants & Analgesics & $\begin{array}{c}\text { Antibacterial } \\
\text { drugs }\end{array}$ & Diaberics & $\begin{array}{c}\begin{array}{c}\text { Sex } \\
\text { hormones }\end{array} \\
\end{array}$ & $\begin{array}{c}\begin{array}{c}\text { Rheumatic } \\
\text { diseases, gout }\end{array} \\
\end{array}$ & Otherst & Total & \\
\hline $\begin{array}{l}1 \\
2 \\
3 \\
4 \\
5\end{array}$ & $\begin{array}{l}21.7 \\
17.5 \\
16.6 \\
16.2 \\
14.9\end{array}$ & $\begin{array}{l}4 \cdot 6 \\
5.8 \\
4 \cdot 7 \\
3 \cdot 2 \\
4 \cdot 2\end{array}$ & $\begin{array}{l}3.7 \\
3 \cdot 2 \\
3.1 \\
4 \cdot 1 \\
3 \cdot 2\end{array}$ & $\begin{array}{l}13.8 \\
12.5 \\
10.4 \\
15.9 \\
15.3\end{array}$ & $\begin{array}{l}2.1 \\
4.5 \\
2.9 \\
3.1 \\
3.4\end{array}$ & $\begin{array}{l}7.3 \\
8.7 \\
6.0 \\
5.0 \\
2.8\end{array}$ & $\begin{array}{r}7.5 \\
9 \cdot 4 \\
6 \cdot 9 \\
10 \cdot 0 \\
6.2\end{array}$ & $\begin{array}{l}2.2 \\
2.8 \\
2.8 \\
3.8 \\
1.8\end{array}$ & $\begin{array}{l}2.5 \\
2.1 \\
0.8 \\
5.0 \\
6.8\end{array}$ & $\begin{array}{l}1.2 \\
2.3 \\
2.1 \\
2.5 \\
1.7\end{array}$ & $\begin{array}{l}4.1 \\
4.0 \\
3.5 \\
6.9 \\
5.3\end{array}$ & $\begin{array}{l}1.3 \\
1.2 \\
1.4 \\
1.7 \\
1.7\end{array}$ & $\begin{array}{l}3.4 \\
3.1 \\
3.2 \\
3.3 \\
4.0\end{array}$ & $\begin{array}{l}2.0 \\
1.9 \\
2.4 \\
1.8 \\
2.2\end{array}$ & $\begin{array}{l}7.4 \\
6.3 \\
5.9 \\
7.2 \\
6.3\end{array}$ & $\begin{array}{l}4.1 \\
5.8 \\
3.1 \\
3.6 \\
3.3\end{array}$ & $\left.\begin{array}{l}67 \cdot 2 \\
73.5 \\
59.0 \\
77.0 \\
68.2\end{array}\right\}$ & $69 \cdot 0$ \\
\hline $\begin{array}{r}6 \\
7 \\
8 \\
9 \\
10\end{array}$ & $\begin{array}{l}14 \cdot 6 \\
14 \cdot 3 \\
14 \cdot 1 \\
14.0 \\
13 \cdot 7\end{array}$ & $\begin{array}{l}3.0 \\
3.8 \\
4.6 \\
2.6 \\
3.5\end{array}$ & $\begin{array}{l}4.4 \\
5.6 \\
3.8 \\
4.4 \\
5.4\end{array}$ & $\begin{array}{c}11 \cdot 3 \\
14 \cdot 4 \\
12 \cdot 1 \\
9 \cdot 7 \\
12 \cdot 8\end{array}$ & $\begin{array}{l}2.5 \\
4.3 \\
2.1 \\
2.0 \\
3.1\end{array}$ & $\begin{array}{l}4.4 \\
5.8 \\
2.4 \\
4.0 \\
5.2\end{array}$ & $\begin{array}{r}4.8 \\
6.7 \\
7.7 \\
6.7 \\
12.6\end{array}$ & $\begin{array}{l}2.1 \\
2.4 \\
2.5 \\
2.7 \\
3.5\end{array}$ & $\begin{array}{l}6.5 \\
5.8 \\
4.9 \\
1.6 \\
3.9\end{array}$ & $\begin{array}{l}2.1 \\
1.6 \\
1.6 \\
1.8 \\
2.3\end{array}$ & $\begin{array}{l}3.8 \\
4.2 \\
4.0 \\
3.6 \\
6.7\end{array}$ & $\begin{array}{l}1.6 \\
1.9 \\
1.9 \\
1.4 \\
2.0\end{array}$ & $\begin{array}{l}2 \cdot 1 \\
3.3 \\
4.0 \\
2 \cdot 8 \\
3 \cdot 7\end{array}$ & $\begin{array}{l}2.8 \\
5.4 \\
4.1 \\
2.3 \\
2.5\end{array}$ & $\begin{array}{l}5.2 \\
7.3 \\
6.6 \\
6.2 \\
7.6\end{array}$ & $\begin{array}{l}2.6 \\
4.2 \\
3.9 \\
2.8 \\
2.9\end{array}$ & $\left.\begin{array}{l}59 \cdot 2 \\
76 \cdot 7 \\
66 \cdot 2 \\
54 \cdot 7 \\
77 \cdot 7\end{array}\right\}$ & 66.9 \\
\hline $\begin{array}{l}11 \\
12 \\
13 \\
14 \\
15\end{array}$ & $\begin{array}{c}12.5 \\
11.8 \\
10.9 \\
9.2 \\
5.6\end{array}$ & $\begin{array}{l}1.9 \\
3.5 \\
2.1 \\
2.3 \\
2.6\end{array}$ & $\begin{array}{l}2.6 \\
3.4 \\
3.3 \\
2.7 \\
2.3\end{array}$ & $\begin{array}{r}11.0 \\
111.9 \\
8 \cdot 0 \\
8.8 \\
5.7\end{array}$ & $\begin{array}{l}2.4 \\
3.3 \\
2.1 \\
2.7 \\
2.0\end{array}$ & $\begin{array}{l}3.2 \\
4.1 \\
3.2 \\
4.2 \\
2 \cdot 1\end{array}$ & $\begin{array}{l}5.4 \\
8.9 \\
4.3 \\
6.2 \\
6.3\end{array}$ & $\begin{array}{l}2.4 \\
2.5 \\
1.6 \\
2.8 \\
2.2\end{array}$ & $\begin{array}{l}3.9 \\
4.4 \\
3.2 \\
2.7 \\
1.6\end{array}$ & $\begin{array}{l}1.2 \\
1.7 \\
1.7 \\
1.8 \\
1.0\end{array}$ & $\begin{array}{l}3.8 \\
4.1 \\
2.0 \\
3.6 \\
2.9\end{array}$ & $\begin{array}{l}1.4 \\
1.7 \\
1.2 \\
1.4 \\
1.6\end{array}$ & $\begin{array}{l}2.5 \\
3.6 \\
2.6 \\
2.9 \\
2.7\end{array}$ & $\begin{array}{l}2.8 \\
2.3 \\
3.1 \\
3.0 \\
3.9\end{array}$ & $\begin{array}{l}6.4 \\
5.8 \\
4.9 \\
4.1 \\
4.9\end{array}$ & $\begin{array}{l}2.8 \\
3.3 \\
2.6 \\
2.5 \\
2.0\end{array}$ & $\left.\begin{array}{l}53 \cdot 8 \\
64.6 \\
45.9 \\
51.7 \\
43 \cdot 8\end{array}\right\}$ & $52 \cdot 0$ \\
\hline \multicolumn{2}{|c|}{$\begin{array}{l}\text { Mean defined } \\
\text { daily dose }\end{array}$} & $3.5 * *$ & 3.7 & $11.6^{*}$ & $2 \cdot 8$ & $4 \cdot 6^{*}$ & $7 \cdot 3$ & 2.5 & 3.7 & 1.8 & $4 \cdot 2^{\star}$ & 1.6 & $3 \cdot 1$ & 2.8 & 6.1 & $3 \cdot 3^{*}$ & $62 \cdot 6$ & \\
\hline
\end{tabular}

**Non-parametric correlation $<0.001$ probability; * $<0.005$ probability, †Others include antacids, antispasmodics, antihypertensive agents, cromoglycate and related drugs, antifungal agents, and antiviral agents.

and managing prescribing in general practice must increasingly be based on this technique. Two aspects of the work we have reported deserve further comment: trends over time in fundholding practices and budget setting.

PRESCRIBING TRENDS IN FUNDHOLDING PRACTICES OVER TIME

Using the defined daily dose method to compare prescribing patterns shows that although cost per patient rose by an average of $8 \%$ for the three groups of practices, the volume of drugs prescribed fell by $8 \%$ $(12 \%$ for Tayside fundholders, $5 \%$ for Grampian fundholders, $9 \%$ for controls). The overall rise in cost per patient was explained by the $19 \%$ rise in unit costs of these drugs $(11 \%$ for Tayside fundholders, $16 \%$ for Grampian fundholders, $24 \%$ for controls). This suggests that all doctors in our study have responded to pressures on them to prescribe at generally lower levels of volume, but also that fundholders responded more effectively in holding down their unit cost of drugs. The $8 \%$ difference in increase in unit cost between Grampian fundholders and controls $(24 \%$ increase minus $16 \%$ increase) is equivalent to $£ 19000$ a year for a practice of 10000 patients for the 11 main British National Formulary sections and a possible difference of $£ 38000$ if these trends were to apply across all drug sections (see appendix 2).

Further work may enable us to determine whether the reduction in volume found in all the practices, and the relative reduction in unit cost by fundholders, was achieved at the expense of what are currently thought of as indicators of "quality" prescribing. The volume and mix of drugs within a British National Formulary section can be analysed, the most obvious example being the use of generic substances as opposed to their proprietary equivalents. At the level of analysis presented in this paper the general downward trends in volume were reversed in three important classes of drugs where current thinking has advocated the need for more prescribing or for more expensive prescribing - namely, ulcer healing drugs, inhaled steroids, and antidepressants.

Antidepressant prescribing is an interesting example to analyse in more detail because of the recent introduction of selective serotonin reuptake inhibitors, which are more expensive than other antidepressants. ${ }^{18}$ Table VI shows defined daily doses per patient over the period of our study for the three groups of practices. The percentage of antidepressants represented by selective serotonin reuptake inhibitors began at $2 \cdot 7 \%$ for Tayside fundholders, $3.2 \%$ for Grampian fundholders, and $8 \%$ for Grampian controls. By the end of the two years all three groups had increased their volume of antidepressants prescribed, but the controls had raised their proportion of selective serotonin reuptake inhibitors to $39.9 \%$, twice that in the fundholding practices. This suggests that the practices with cash limited budgets progressed more cautiously towards introducing an expensive preparation. Analyses of this kind will be extended to other classes of drugs.

\section{SETTING BUDGETS AND PRESCRIBING AMOUNTS}

Table I shows the wide variation of funds set on the basis of historic prescribing cost. The absence of a consistent relation between the funds set and either the actual spending or the age mix of the practices shows the need to find a better process for fund allocation. In addition, the equity implications of practices of 10000 patients receiving allocations differing by as much as $£ 200000$ on the basis of historical activity alone needs to be addressed with some urgency.

Table $\mathrm{V}$ shows large variations in volume levels within British National Formulary sections as well as a relation between age and volume for some sections. The table allows individual practices to identify areas where their volumes differ from the mean. This mean defined daily dose per patient could be taken as a target volume for each British National Formulary section which practices could aim to direct their prescribing behaviour towards. For those sections related to age a mean can be calculated for each of the three age bands presented. For example, for diuretics the target volumes for the three age bands shown in the table and based on proportion of patients aged 65 or over would be $13 \cdot 6,12 \cdot 1$, and $9 \cdot 1$ defined daily doses. A similar method could be used to calculate cost per volume targets.

The analysis we have described should be further developed on a regional basis. At this level other demographic factors could be incorporated in the calculation of a range of volume targets across British National Formulary sections. With a larger number of practices the balance between historic patterns and regional targets should be more easily achieved. The result would be fund allocations which are more equitable than at present and could be used for all practices, whether fundholding or not. This would

TABLE VI-Defined daily doses per patient for selective serotonin reuptake inhibitors versus other antidepressants from November 1990 to October 1992

\begin{tabular}{|c|c|c|c|c|c|c|c|c|}
\hline & \multicolumn{8}{|c|}{ Quarters of data for two years starting November 1990} \\
\hline & 1 st & 2nd & 3rd & 4th & 5 th & 6th & 7th & 8th \\
\hline \multicolumn{9}{|c|}{ Selective serotonin reuptake inhibitors } \\
\hline $\begin{array}{l}\text { Tayside } \\
\text { Grampian } \\
\text { Controls }\end{array}$ & $\begin{array}{l}0.03 \\
0.02 \\
0.06\end{array}$ & $\begin{array}{l}0.04 \\
0.05 \\
0.07\end{array}$ & $\begin{array}{l}0.07 \\
0.06 \\
0.11\end{array}$ & $\begin{array}{l}0.10 \\
0.09 \\
0.14\end{array}$ & $\begin{array}{l}0 \cdot 10 \\
0 \cdot 10 \\
0 \cdot 20\end{array}$ & $\begin{array}{l}0.14 \\
0.12 \\
0.22\end{array}$ & $\begin{array}{l}0.14 \\
0.18 \\
0.31\end{array}$ & $\begin{array}{l}0.22 \\
0.18 \\
0.36\end{array}$ \\
\hline \multicolumn{9}{|c|}{ Other antidepressants } \\
\hline $\begin{array}{l}\text { Tayside } \\
\text { Grampian } \\
\text { Controls }\end{array}$ & $\begin{array}{l}0.94 \\
0.67 \\
0.66\end{array}$ & $\begin{array}{l}0.93 \\
0.77 \\
0.72\end{array}$ & $\begin{array}{l}0.98 \\
0.80 \\
0.71\end{array}$ & $\begin{array}{l}1.06 \\
0.76 \\
0.68\end{array}$ & $\begin{array}{l}0.93 \\
0.76 \\
0.65\end{array}$ & $\begin{array}{l}0.95 \\
0.66 \\
0.58\end{array}$ & $\begin{array}{l}0.69 \\
0.71 \\
0.56\end{array}$ & $\begin{array}{l}0.96 \\
0.66 \\
0.54\end{array}$ \\
\hline \multicolumn{9}{|c|}{ Selective serotonin reuptake inhibitors as \% of all antidepressants } \\
\hline $\begin{array}{l}\text { Tayside } \\
\text { Grampian } \\
\text { Controls }\end{array}$ & $\begin{array}{l}2 \cdot 7 \\
3 \cdot 2 \\
8 \cdot 0\end{array}$ & $\begin{array}{l}3 \cdot 8 \\
5 \cdot 8 \\
9 \cdot 1\end{array}$ & $\begin{array}{r}6 \cdot 7 \\
7 \cdot 4 \\
13 \cdot 4\end{array}$ & $\begin{array}{r}8 \cdot 4 \\
10 \cdot 3 \\
17 \cdot 0\end{array}$ & $\begin{array}{r}9 \cdot 6 \\
11 \cdot 7 \\
23 \cdot 7\end{array}$ & $\begin{array}{l}13 \cdot 1 \\
15 \cdot 1 \\
27 \cdot 7\end{array}$ & $\begin{array}{l}16 \cdot 7 \\
19 \cdot 9 \\
35 \cdot 2\end{array}$ & $\begin{array}{l}18.4 \\
20.8 \\
39.9\end{array}$ \\
\hline
\end{tabular}


confirm the move away from regarding cost per patient as the principal determinant of budgets.

We thank those practices that allowed us access to their prescribing data, the pharmacy practice division for providing the data, David Clucas of the prescribing research unit at Leeds University, and the Scottish Home and Health Department, that funded the Shadow fundholding project.

\section{Appendix 1-Calculating defined daily doses}

SPA LEVEL 2 DATA CURRENTLY AVAILABLE

\begin{tabular}{lcc}
\hline Drug prescribed & $\begin{array}{c}\text { No of } \\
\text { prescriptions }\end{array}$ & $\begin{array}{c}\text { Quantity } \\
\text { (tablets, etc) }\end{array}$ \\
\hline Cimetidine $200 \mathrm{mg}$ & 8 & 240 \\
Cimetidine $400 \mathrm{mg}$ & 20 & 600 \\
Ranitidine $150 \mathrm{mg}$ & 14 & 280 \\
Ranitidine $300 \mathrm{mg}$ & 9 & 180 \\
Omeprazole $20 \mathrm{mg}$ & 18 & 540 \\
\hline
\end{tabular}

DEFINED DAILY DOSES (AS FOUND IN WHO SYSTEM)

\begin{tabular}{lr}
\hline Drug & Dose \\
\hline Cimetidine & $800 \mathrm{mg}$ \\
Ranitidine & $300 \mathrm{mg}$ \\
Omeprazole & $20 \mathrm{mg}$ \\
\hline
\end{tabular}

\section{CALCULATION}

The number of defined daily doses (ddds) for each prescription of a drug is:

(quantity $\times$ dose)/WHO defined daily dose for that drug. Thus:

\begin{tabular}{|c|c|c|c|}
\hline Drug prescribed & Quantity $\times$ dose + ddd & $\begin{array}{l}\text { No of ddds } \\
\text { per } \\
\text { prescribed } \\
\text { item }\end{array}$ & $\begin{array}{l}\text { Total ddds } \\
\text { for all } \\
\text { prescriptions }\end{array}$ \\
\hline Cimetidine $200 \mathrm{mg}$ & $(240 \times 200=48000) / 800$ & $60 \times 8$ & 480 \\
\hline Cimetidine $400 \mathrm{mg}$ & $(600 \times 400=240000) / 800$ & $10300 \times 20$ & 06000 \\
\hline Ranitidine $150 \mathrm{mg}$ & $(280 \times 150=42000) / 300$ & $0 \quad 140 \times 14$ & 41960 \\
\hline Ranitidine 300 mg & $(180 \times 300=54000) / 300$ & $180 \times 9$ & 91620 \\
\hline \multirow[t]{2}{*}{ Omeprazole $20 \mathrm{mg}$} & $(540 \times 20=10800) / 20$ & $540 \times 18$ & 89720 \\
\hline & & & 19780 \\
\hline
\end{tabular}

Drugs prescribed: 6480 ddds of cimetidine, 3580 ddds of ranitidine, 9720 ddds of omeprazole.

Total $=19780$ ddds of ulcer healing drugs.
Appendix 2-Potential difference between Grampian fundholders' control practices

Assume two practices with:

- 100 ddds per year

- At 24p per ddd per patient at start of period

- List size of 10000

- Fundholder increases cost per volume at $16 \%$

- Control increases cost per volume at $24 \%$

By period 3:

Fundholder costs are $(100 \times(0 \cdot 24 \times 1 \cdot 16)) \times 10000=$

278400

Control costs are $(100 \times(0 \cdot 24 \times 1 \cdot 24)) \times 10000=297600$

Difference (for 11 British National Formulary sections)

If 11 sections explain half of all prescribing

1 Department of Health. Working for patients. London: HMSO, 1989 (CM 555). 2 Scottish Office Home and Health Department. Funding general practice: the programme for the introduction of general practice funds. Edinburgh: HMSO, 1990.

3 Howie JGR, Heaney DJ, Maxwell M, Porter AMD, Hopton JL, Light CJ. The Scottish general practice shadow fund-holding project: outline of an evaluation. Health Bulletin 1992;50:316-28.

4 Howie JGR, Heaney DJ, Maxwell M. Evaluation of the Scottish shadow fundholding project: first results. Health Bulletin 1993;51:94-105.

5 Glennerster H, Owens P, Matsaganis M. A foothold for fundholding. London: King's Fund Institute, 1992

6 Bain J. Budget holding: a step into the unknown. $B M \Im 1991 ; 302: 771-3$.

7 Bain J. Budget holding in Calverton: one year on. BMF 1992;304:971-3.

8 Bain J. The second year: budget holding: here to stay? $B M \mathcal{F} 1993 ; 306: 1185-8$.

9 Coulter A, Bradlow J. Effect of NHS reforms on general practitioner's referral patterns. $B M \mathcal{F}$ 1993;306:433-7.

10 Newton J, Fraser M, Robinson J, Wainwright D. Fundholding in Northern region: the first year. $B M \mathcal{F} 1993 ; 306: 375-8$.

11 World Health Organisation Collaborating Centre for Drug Statistics Methodology. Guidelines for defined daily doses. Oslo: World Health Organisation, 1991.

12 Nordic Council on Medicines. Nordic statistics on medicines 1981-1983 Part I Uppsala: Nordiska Läkemedels Nämnden, 1985 (No 14).

13 Nordic Council of Medicines. Nordic statistics on medicines 1981-1983. Part II. Nordic drug index with classification and defined daily doses. Uppsala: Nordiska Läkemedels Nämnden, 1985 (No 15).

14 Nordic Council on Medicines. Nordic statistics on medicines 1981-1983. Part III. Guidelines for anatomical therapeutic chemical classification. Uppsala: Nordiska Läkemedels Nämnden, 1985 (No 16)

15 Wuatt TD, Passmore CM, Morrow NC, Reilly PM. Antibiotic prescribing: the need for a policy in general practice. $B M \mp 1990 ; 300: 441-4$.

16 Purves IN, Edwards C. Comparison of prescribing unit with index including both age and sex in assessing general practice prescribing costs. BMF 1993;306:496-8.

17 Sleater DJD. Towards accurate prescribing analysis in general practice: accounting for the effects of practice demography. British fournal of General Practice 1993;43:102-6.

18 University of Leeds, School of Public Health. Treatment of depression in primary care. London: NHS Management Executive, 1993 (Effective Health Care No 5).

(Accepted 22 fuly 1993)

\section{A MEMORABLE PATIENT}

\section{Restoration of a brilliant mind}

She was in her 80 s, a distinguished elderly academic who had been a regular visitor to our outpatient department with her advancing osteoporosis. She enjoyed the hospital waiting room, engaging herself deeply in conversation about old Bermondsey with random neighbours or commenting on the distinguished persons, commemorated on the plaques on the walls, many of whom she or her family had known personally and socially. I was startled to realise that almost two years must have passed since I had last seen her when her general practitioner telephoned me with the sad news that she was "on the way out," confused, short of breath, and confined to her armchair and bed. Her ancient nanny had died a few weeks before and she was alone in her dark old apartment. Could we admit her to make her last few days more comfortable?

Her once brilliant mind was unravelled indeed. Pallid, wild eyed, and breathing with great difficulty she seemed to be in extremis. Since nanny died her calories had come mainly from her substantial stock of good clarets. Her pallor had a lemon tint and her pernicious anaemia was promptly diagnosed and confirmed. A large retrosternal goitre explained much of her respiratory difficulty and her

accompanying hypothyroidism also contributed to the diagnostic complex.

More balanced nutrition with liberal vitamins, vitamin B-12 by injection, careful thyroxin replacement, and the passage of time saw a miraculous transformation. The proof of cure was the manuscript that, four months later, she prepared and submitted to a learned journal. I treasure my now yellowing copy which contains her paper, much of it drawn from her own memory, experiences, and research. Closely argued, it cast new light on a well known Victorian historical episode.

I had seen reversible dementia in the elderly before and I have seen it since but that extraordinary restoration of a brilliant human mind was one of my more unforgettable clinical experiences and the substance of much passionate teaching thereafter.-HARRY KEEN is emeritus professor of medicine in London

We are delighted to receive submissions of up to 600 words on $A$ paper (or patient or book) that changed my practice, $A$ memorable patient, The one message I would like to leave behind, or related topics. 